УДК:811.111:81’373.43

DOI https://doi.org/10.26661/2414-1135-2021-83-33

\title{
РОЗШИРЕННЯ СЛОВНИКОВОГО СКЛАДУ АНГЛІЙСЬКОЇ МОВИ У 2020 РОЦІ
}

\author{
Рудик I. М. \\ кандидат філологічних наук, доцент, \\ доиент кафедри міжкультурної комунікаиії та прикладної лінгвістики \\ Житомирський державний університет імені Івана Франка \\ вул. Велика Бердичівська, 40, Житомир, Україна \\ orcid.org/0000-0002-6621-5990 \\ irina4new@gmail.com
}

\author{
Ключові слова: семантичний \\ неологізм, лексичний \\ неологізм, телескопія, \\ семантика, пандемія, \\ COVID-19.
}

Дослідження мови як динамічної соціальної системи невідривно пов'язане 3 аналізом зовнішніх факторів, які стимулюють мову до змін. Особливе місце серед таких факторів посідає зв'язок мови із суспільством, зміни життя якого призводять до появи в мові неологізмів. За результатами аналізу останніх публікацій і колекцій «Слово року», англомовні неологізми, утворені протягом двох останніх десятиліть, переважно належать до таких тематичних груп, як Інтернет-технології та соціальні комунікації, технічні розробки, політично-економічні умови й реалії, а також кліматичні проблеми й засоби реагування на них.

У 2020 році колектив словника Oxford English Dictionary вперше не зміг визначити слово року й натомість оприлюднив доповідь під назвою Words of an unprecedented year. Представлене дослідження має на меті аналіз семантики активно вживаних неологізмів, породжених COVID-19, і встановлення тематичних груп, до яких вони належать.

3-поміж понад 1000 нових лексичних одиниць чи словосполучень, утворених в англійській мові протягом 2020 року, значна частка припадає на одиниці, що позначають коронавірусну хворобу. Інші одиниці залежно від їх предметно-понятійних ознак можна розподілити за кількома тематичними групами.

Першу групу утворюють назви нових суспільних об'єднань у тому числі за професійною належністю (наприклад, critical workers, support bubble, childcare bubble, quarantine pod, covidiots, anti-maskers тощо). До другої тематичної групи включаємо лексичні одиниці на позначення нових форм комп'ютерно-опосередкованої взаємодії (наприклад, Zoombie, Zoombombing, covideo parties, quarantini тощо). Третя тематична група містить назви нових технологічних реалій і режимів роботи (наприклад, WFH (working from home), workation, staycation, remote learning, remote working тощо).

Таким чином, одну 3 провідних тенденцій у розширенні словникового складу англійської мови у 2020 році вбачаємо в зосередженості на соціальних зв'язках, що проявляється в активному творенні нової лексики на позначення як міжособистісної взаємодії, так і різних видів колективів. Інша тенденція, на думку автора, полягає в увазі до організації робочого процесу в нових умовах. 


\title{
2020 VOCABULARY EXPANSION IN MODERN ENGLISH
}

\author{
Rudyk I. M. \\ Candidate of Philological Sciences, Associate Professor, \\ Associate Professor at the Department of Intercultural Communication and Applied Linguistics \\ Zhytomyr Ivan Franko State University \\ Velyka Berdychivska str., 40, Zhytomyr, Ukraine \\ orcid.org/0000-0002-6621-5990 \\ irina4new@gmail.com
}

Key words: semantic neologism, lexical neologism, blending, semantics, pandemics, COVID-19.
Studying language as a dynamic system is intrinsically linked to analyzing external factors that stimulate changes in the language. The leading role here is played by the relationship between language and society, with changes in the social texture resulting in neologisms. The analysis of recent publications and 'Word of the Year' collections suggests that English neologisms coined over the last two decades tend to belong to such thematic groups as Internet technologies and social communications, technical developments, political and economic conditions, and climate change challenges and responses.

In 2020, the Oxford English Dictionary team found themselves unable to identify one single word of the year, and instead published a 38-page Words of an unprecedented year report. The paper under consideration seeks to analyze the semantics of frequently used COVID-19 neologisms, as well as identify the thematic groups they belong to.

Out of over 1,000 new lexical units and phrases coined in English in 2020, many are used to denote the coronavirus disease. Other units, based on their conceptual features, can fall into three main thematic groups.

Group 1 contains names of new social networks, including those of professional groups (for example, critical workers, support bubble, childcare bubble, quarantine pod, covidiots, anti-maskers, etc.). Lexical units in thematic group 2 denote new forms of computer mediated communication (for example, Zoombie, Zoombombing, covideo parties, quarantini, etc.). Thematic group 3 is made up of units for new technologies and work modes (for example, WFH (working from home), workation, staycation, remote learning, remote working, etc.).

The results above give us grounds to consider a focus on social links to be one of the leading 2020 tendencies of vocabulary expansion in Modern English. In line with this tendency, new vocabulary units are systematically coined to denote both interpersonal interactions and various types of social networks. Another tendency as viewed by the author is ample attention to implementing new work processes in a changed environment.
Здатність до розвитку, як відомо, є способом існування мови як динамічної соціальної системи. До чинників, які стимулюють мову до змін, належать зовнішні й внутрішні фактори, серед яких провідну роль відіграє зв'язок із суспільством. Цей зв'язок, зокрема, проявляється в появі неологізмів, пов'язаних із певним аспектом життя соціуму. Аналіз останніх публікацій і колекцій «Слово року» (започаткованих у 2003-2004 роках) свідчить про те, що такі лексичні одиниці й словосполучення 3 високою частотою вживання в англійській мові переважно належать до таких тематичних груп:
- нові Інтернет-технології та соціальні комунікації, наприклад: blog (2004), podcast (2005), tweet (2009), unfriend (2009), 9 (a 'Face With Tears of Joy' етојі: названий «словом» року від видавництва Oxford University Press у 2015 році), w00t/woot (a slang interjection to express happiness or excitement, usually used in online conversations);

- нові політично-економічні умови й реалії, наприклад: credit crunch (2008), big society (2010), squeezed middle (as a social class, 2011), omnishambles (2012);

- нові кліматичні проблеми й засоби реагування на них, наприклад: carbon-neutral (2006), 
carbon footprint (2007), climate emergency (2019), climate strike (2019);

- нові технічні розробки, наприклад: selfie (2013), vape (2014).

Однак цю тенденцію до створення нових одиниць у сферах Інтернет-технологій і соціальних комунікацій, технічних розробок, політично-економічних реалій, а також кліматичних проблем було порушено у 2020 році. Щоб усвідомити масштаб впливу подій 2020 року на розвиток англійської мови, достатньо зважити лише один факт. У 2020 році колектив словника Oxford English Dictionary вперше не зміг визначити слово року й натомість оприлюднив доповідь під назвою Words of an unprecedented year. На 38 сторінках доповіді викладено лексичні одиниці з найвищою частотою вживання в кожному окремому місяці 2020 року, а також проаналізовано основні тенденції розвитку англійської мови в минулому році [1].

Необхідність вивчити такі тенденції, а також виокремити основні тематичні групи, до яких належать пов'язані з пандемією одиниці з високою частотою вживання, зумовлює актуальність представленого дослідження. Метою роботи $є$ аналіз семантики активно вживаних неологізмів, породжених COVID-19, і встановлення тематичних груп, до яких вони належать.

За даними британського лексикографа Тоні Торна, унаслідок пандемії COVID-19 в англійській мові з'явилося понад 1000 нових лексичних одиниць чи словосполучень [2]. Природно, що високу питому вагу серед них мають одиниці на позначення власне захворювання, яке спричинило пандемію. До них належать: corona, Rona, Lady Rona, Miss Rona, roni, rone, the pandy, the pando.

Інші лексичні одиниці із цього списку можна розподілити за кількома тематичними групами залежно від їх предметно-понятійних ознак.

Тематична група 1: нові суспільні об'єднання

Одне із центральних місць серед тематичних груп посідає група одиниць на позначення нових суспільних об'єднань. По-перше, сюди відносимо назви нових соціальних утворень, таких як support bubble, childcare bubble тощо, наприклад:

Self-isolate immediately if [...] someone in your support bubble tested positive and you've been in close contact with them since they had the test or in the 48 hours before their test [3].

The list of reasons you can leave your home and area include, but are not limited to [...] visiting those in your support bubble - or your childcare bubble for childcare [4].

Визначення зазначених суспільних об'єднань та умови їх формування знаходимо на урядовому порталі Об’єднаного Королівства gov.uk:
A support bubble is a support network which links 2 households. You have to meet certain eligibility rules to form a support bubble.

A childcare bubble is where one household links with one other household to provide informal childcare to anyone under 14. All adults in both households must agree to this arrangement. 'Informal' childcare means it is unpaid and unregistered [4].

У медійному просторі США фіксуємо посилання на аналогічні об'єднання, але під іншими назвами: (quarantine/pandemic) pod, container i quaranteam, наприклад:

Pods are small, self-contained networks of people who limit their non-distanced social interaction to one another - in other words, they're the small group of people with whom you share air without using breath-control precautions such as masks [5].

Іншим різновидом суспільного об'єднання, назва якого активно вживалася у 2020 році, є keyworkers, frontliners, essential workers або critical workers:

Critical workers whose work is critical to the coronavirus (COVID-19) and EU transition response include those who work in health and social care and in other key sectors [4].

Цю групу, як бачимо, сформовано за професійною належністю; до неї зазвичай включають не лише представників медичної, а й соціальної сфери, наприклад, виробників і продавців продуктів харчування, окремі категорії освітян, релігійних працівників, журналістів, працівників органів місцевого самоврядування тощо.

Наведені вище неологізми є семантичними, оскільки їх утворено шляхом оновлення значення вже наявних одиниць. Поряд із ними високу частотність уживання в минулому році демонстрували такі лексичні неологізми, як covidiot (телескопний іменник: covid + idiot) та anti-masker (похідний іменник, утворений від основи mask інтернаціональним словотвірним елементом anti й суфіксом -er). Водночас корпуси сучасної англійської мови досі не реєструють випадки вживання іменника covidiot, в англомовних словниках його вже розтлумачено як людину, яка дратує інших, відмовляючись дотримуватися правил соціального дистанціювання, установлених для запобігання поширенню COVID-19 (переклад наш - I. P., за [6]). Англомовні засоби масової інформації також активно вживають цю нову лексичну одиницю, утворену шляхом злиття основ (Covid i idiot), наприклад:

One traveller said the Tui flight was full of "covidiots" and "inept crew who couldn't care less" [7].

Лексична одиниця superspreader із цієї ж категорії є не новою в англійській мові, функціонуючи з 1970-х років, однак частотність іiї вживання 
у 2020 році значно зросла, особливо в жовтні 2020 року, після численних випадків захворювання в Білому Домі.

Тематична група 2: нові режими роботи

Розглянувши назви нових суспільних об'єднань, викликаних до життя у 2020 році, перейдемо до розгляду наступної тематичної групи - нових режимів роботи. Сюди включаємо абревіатуру WFH (working from home), а також численні словосполучення з означенням remote: remote learning, remote working/work/worker, remote workforce, remote instruction. Так, у статті від 21 грудня 2020 року під назвою Remote Work Statistics: Navigating the New Normal уживається ціла низка зазначених одиниць:

According to Upwork, $41.8 \%$ of the American workforce continues to work remotely. Although an estimated $26.7 \%$ will still be working from home through 2021, 36.2 million Americans (22\% of the workforce) will be working remotely by 2025. This is a staggering $87 \%$ increase from the number of remote workers prior to the pandemic! [8].

До складу цієї групи відносимо також лексичну одиницю workation (іменник і дієслово), утворену шляхом телескопії, через злиття основ work i vacation. Вона позначає подорож, яка поєднує в собі можливості відпочивати й водночас займатися роботою. У статті від 21 жовтня 2020 року, наприклад, цю одиницю вжито в самому заголовку:

4 TOP READS FOR YOUR NEXT WORKATION OR STAYCATION [9].

Як бачимо, крім workation, наведений приклад містить інший близький за значенням телескопний іменник - staycation - на позначення відпустки, проведеної у своїй країні або навіть удома, з одноденними поїздками до місцевих визначних місць. Варто зазначити, що як workation, так і staycation увійшли до англійської мови ще до 2020 року, однак у контексті пандемії частота їх уживання зросла на 500\% і 380\% відповідно [10].

Тематична група 3: нові форми комп'ютерно-опосередкованої взасмодії

До цієї тематичної групи відносимо численні лексичні неологізми, пов'язані передусім із платформою Zoom, наприклад:

Zoombombing - hijacking and/or interrupting videoconferencing on the Zoom platform.

У зв'язку 3 необхідністю взаємодіяти в онлайн-режимі, небачену досі частоту вживання зафіксовано в дієслова иптите [1]. Що стосується власне учасників зустрічей у режимі відеоконференції, ї описують такі лексичні одиниці:

- Zoombie - 1) someone incapacitated by too much screen time, or 2) a malicious disruptor of a videoconference;
- Zoom-fatigued, Zoomed out - exhausted and/ or disoriented after spending too much time in videoconferences.

Крім того, дослідник Т. Торн фіксує використання іменника Zoom для трансформації фразеологічної одиниці 'the elephant in the room'. У результаті утворюється контамінований фразеологізм, який описує випадкового (а тому небажаного) гостя в кадрі під час відеоконференції:

- the elephant in the Zoom - an unmentioned presence or unacknowledged issue in an online meeting.

Зафіксовано також одиниці на позначення зовнішнього вигляду учасників відеоконференцій, зокрема upperwear - одяг вище поясу; й зовнішнього вигляду приміщення, наприклад:

Zoom room - part of one's home kept clean and inviting for use as videocalling background.

Низка одиниць уживається на позначення неформальних зустрічей у режимі відеоконференціi: videoparties, covideo parties, zoom parties. 3 ними пов'язані такі неологізми:

- quarantini (телескопія: quarantine + martini) - a martini mixed and consumed in conditions of confinement;

- locktail hour (телескопія: lockdown + cocktail) - a time allotted to consumption of cocktails while isolating [11].

Висновки. Таким чином, аналіз предметно-понятійних ознак активно вживаних неологізмів, пов'язаних із COVID-19, дає змогу виокремити такі їх типи:

- назви нових суспільних об'єднань,

- назви нових режимів роботи,

- назви нових технологічних реалій і пов'язаних із ними особливостей комп'ютерно-опосередкованої соціальної взаємодії.

За способом виникнення досліджувані інновації належать як до семантичних неологізмів ( з інноваціями лише на рівні змісту), так і до лексичних (з інноваціями на рівні й змісту, і форми). За попередньо отриманими даними, одну з провідних тенденцій у розширенні словникового складу англійської мови у 2020 році вбачаємо в зосередженості на соціальних зв'язках, що проявляється в активному творенні нової лексики на позначення як міжособистісної взаємодії, так і різних видів колективів. Іншу тенденцію вбачаємо в увазі до нових форм організації робочого процесу в пост-пандемічних умовах.

Перспектива подальших наукових розвідок може полягати в дослідженні запозичень виявлених мовних одиниць 3 англійської до інших мов. 


\section{ЛIТЕРАТУРА}

1. Words of an unprecedented year. URL: https:// languages.oup.com/word-of-the-year/2020/ (accessed: 15.01.2021).

2. Covidiots? Quarantinis? Linguist explains how COVID-19 has infected our language. CBC/ Radio-Canada. URL: https://www.cbc.ca/radio/ thecurrent/the-current-for-april-22-2020$1.5540906 /$ covidiots-quarantinis-linguistexplains-how-COVID-19-has-infected-ourlanguage-1.5540914 (accessed: 21.01.2021).

3. National Health Service. URL: https://www. nhs.uk/conditions/coronavirus-COVID-19/selfisolation-and-treatment/when-to-self-isolateand-what-to-do/ (accessed: 02.02.2021).

4. National lockdown: Stay at Home. 4 January 2021. URL: https://www.gov.uk/guidance/ national-lockdown-stay-at-home (accessed: 06.01.2021).

5. How to Form a Pandemic Pod. URL: https:// greatergood.berkeley.edu/article/item/how to form a pandemic pod (accessed: 24.01.2021).

6. Oxford Learner's Dictionary. Oxford University Press, 2021. URL: https://www. oxfordlearnersdictionaries.com/ (accessed: 27.01.2021).

7. Coronavirus: 'Covidiots' criticised on Tui quarantine flight. BBC News. 31.08.2020. URL: https://www.bbc.com/news/uk-53970217 (accessed: 24.01.2021).

8. Courtney E. Remote Work Statistics: Navigating the New Normal. 21 December 2020. URL: https://www.flexjobs.com/blog/post/remotework-statistics/ (accessed: 25.01.2021).

9. 4 top reads for your next workation or staycation to suit your style. 16 October 2020. URL: https:// www.marinabaysands.com/singapore-visitorsguide/around-mbs/4-top-reads-for-workation-orstaycation.html (accessed: 25.01.2021).

10. OED Word of the Year expanded for 'unprecedented' 2020. 23 November 2020. URL: https://www.bbc.com/news/entertainment-arts55016543\#: :text=This\%20year\%20has\%20 seen $\% 20$ so, $\% 2 \mathrm{C} \% 20 \operatorname{mood} \% 2 \mathrm{C} \% 20$ or $\% 20$ preoccupations $\% 22$ (accessed: 26.01.2021).

11. Thorne T. \#CORONASPEAK - the language of COVID-19 goes viral -2. URL:https://languageand-innovation.com/2020/04/15/coronaspeak-
part-2-the-language-of-COVID-19-goes-viral/ (accessed: 26.01.2021).

\section{REFERENCES}

1. Words of an unprecedented year (2021). URL: $\mathrm{https}$ ://languages.oup.com/word-of-the-year/2020/.

2. Covidiots? Quarantinis? Linguist explains how COVID-19 has infected our language (2020, April 22). CBC/Radio-Canada. URL: https:// www.cbc.ca/radio/thecurrent/the-current-forapril-22-2020-1.5540906/covidiots-quarantinislinguist-explains-how-COVID-19-has-infectedour-language-1.5540914.

3. National Health Service (2020). URL: https:// www.nhs.uk/conditions/coronavirus-COVID-19/ self-isolation-and-treatment/when-to-selfisolate-and-what-to-do/.

4. National lockdown: Stay at Home (2021, January 4). URL: https://www.gov.uk/guidance/ national-lockdown-stay-at-home.

5. How to Form a Pandemic Pod (2020, July 15). URL: https://greatergood.berkeley.edu/article/ item/how_to_form_a_pandemic_pod.

6. Oxford Learner's Dictionary (2021). URL: https://www.oxfordlearnersdictionaries.com/.

7. Coronavirus: 'Covidiots' criticised on Tui quarantine flight (2020, August 31). BBC News. URL: https://www.bbc.com/news/uk-53970217.

8. Courtney, E. (2020, December 21). Remote Work Statistics: Navigating the New Normal. URL: https://www.flexjobs.com/blog/post/remotework-statistics/.

9. 4 top reads for your next workation or staycation to suit your style (2020, October 16). URL: https:// www.marinabaysands.com/singapore-visitorsguide/around-mbs/4-top-reads-for-workation-orstaycation.html.

10. OED Word of the Year expanded for 'unprecedented' 2020 (2020, November 23). URL: https://www.bbc.com/news/entertainmentarts-55016543\#: : text=This\%20year $\% 20$ has $\% 20$ seen $\% 20$ so, $\% 2 \mathrm{C} \% 20 \operatorname{mood} \% 2 \mathrm{C} \% 20$ or\%20preoccupations $\% 22$.

11. Thorne, T. (2020, April 15). \#CORONASPEAK the language of COVID-19 goes viral - 2. URL: https://language-and-innovation.com/2020/ $04 / 15 /$ coronaspeak-part-2-the-language-ofCOVID-19-goes-viral/. 